\title{
RECENZJA KSIĄŻKI AGATY BACHÓRZ, ROSJA W TEKŚCIE I DOŚWIADCZENIU. ANALIZA WSPÓLCZESNYCH POLSKICH RELACJI Z PODRÓŻY, ZAKLAD WYDAWNICZY NOMOS, KRAKÓW 2013 (341 STRON)
}

Historia uczy, że relacje międzynarodowe w dużej mierze zależą od naszych wyobrażeń o innych. Nie bez znaczenia pozostają głęboko zakorzenione w ludzkiej świadomości stereotypy narodowe czy też dawne lub obecne konflikty polityczne i kulturowe. Dziś więź Polski i Rosji bez wątpienia poddawana jest trudnej próbie. Towarzyszące nam często ambiwalentne odczucia dotyczące Rosji nie ułatwiają obiektywnej oceny sytuacji głośno komentowanej przez media. I choć z jednej strony czujemy pewien respekt przed „rosyjskim imperium”, to z drugiej - jesteśmy ciekawi kraju, który nam, Słowianom, mimo wszystko przypomina rodzimy krajobraz kulturowy. Temat stosunków polsko-rosyjskich od dłuższego czasu towarzyszy przekazom medialnym, społecznym, a także kulturowym. Nieprzypadkowo zatem - w mojej ocenie - pojawiają się w jednym czasie publikacje naukowe dotykające tej tematyki.

Odnosząc się do zjawiska podróży, rozumianego jako poszukiwanie kontaktu z innym światem, Rosja i kraje byłego ZSRR nie są zbyt popularnym celem wyjazdów turystycznych Polaków. Skąd zatem zainteresowanie autorki książki tym tematem? Zdaniem Agaty Bachórz współczesne wyjazdy odkrywają nowy wymiar podróżowania do Europy Wschodniej i, choć nadal pozostają zjawiskiem niszowym, poprzez swoje badania autorka poszukuje odpowiedzi na pytanie, co stoi za takim właśnie wyborem kierunku podróży odwiedzających. Jak czytamy na początkowych kartach książki: „Jesteśmy obecnie świadkami specyficznej, choć stosunkowo wąskiej i typowej jedynie dla wybranych środowisk intelektualnych, mody na

* Mgr, Katedra Socjologii Kultury, Instytut Socjologii, Wydział Ekonomiczno-Socjologiczny, Uniwersytet Łódzki, ul. Rewolucji 1905 r. 41/43, 90-214 Łódź; e-mail: justyna.golebiowska @poczta.fm. 
podróżowanie do Rosji” (s. 9). Nie tylko wspomniana moda decyduje o wyjazdach na Wschód. Autorka cierpliwie i konsekwentnie przekonuje czytelnika o walorach i znaczeniu podróżowania. Na przykładzie Rosji pokazuje, jak cennym doświadczeniem, a czasem wewnętrzną przemianą może okazać się wyjazd do kraju, który z jednej strony jest nam bliski językowo i kulturowo, zaś z drugiej pozostaje „dziki” i nieodkryty, a często z racji historycznych doświadczeń - nawet budzący niechęć.

Recenzowana publikacja liczy 341 stron. Całość podzielona jest na siedem rozdziałów, poprzedzonych wprowadzeniem i domkniętych podsumowaniem, bibliografią oraz aneksem i indeksem rzeczowym.

Książkę rozpoczyna dwudziestostronicowe wprowadzenie, w którym autorka wyjaśnia, z czego wynika jej zainteresowanie relacjami z podróży do Rosji. Agata Bachórz zauważa, że podróżowanie można, a nawet należy postrzegać jako działanie, które zakorzenione jest w ważnych dyskursach kultury. Praca stanowi próbę połączenia dwóch perspektyw: po pierwsze, analizy doświadczeń nabywanych podczas podróży (w celu jednostkowej samorealizacji), po drugie zaś - badania relacji polsko-rosyjskich, z uwzględnieniem miejsca Rosji we współczesnych polskich dyskursach. Niewątpliwie pierwsza perspektywa odnosi się do problemów badawczych socjologii podróży, natomiast kolejna stanowi obszar kształtowania się współczesnych stosunków międzykulturowych, z odwołaniem się do funkcjonujących w ludzkiej świadomości stereotypów. Autorka zwraca uwagę na pewnego rodzaju „renesans” w zainteresowaniu Rosją, co przekłada się na zwiększoną liczbę wyjazdów do tego kraju. Kolejne tezy autorki, dotyczące wzrostu wskaźników natężenia ruchu turystycznego między Polską a Rosją, mówią o: ogólnym zainteresowaniu wyjazdami, poszukiwaniu mniej masowych kierunków wyjazdów oraz modzie (która w tym przypadku nie łączy się z masowością). Swoje założenia Agata Bachórz próbuje poprzeć wiarygodnymi danymi statystycznymi, jednak okazuje się to z wielu względów (opisanych we wstępie) mało realne. Pozostaje zatem ogólna skala i szacowanie zjawiska, co w żaden sposób nie umniejsza walorów książki.

Cel, a właściwie cele, jakie postawiła sobie autorka, są bardzo liczne i można je zebrać w cztery grupy. Pierwsza grupa koncentruje się wokół zagadnień dotyczących podejmowania decyzji o podróży do Rosji - ich przyczyn, motywów oraz elementów, które działają przyciągająco na turystów, jak również tych fragmentów indywidualnych biografii podróżników, które mogły zdecydować o wyborze destynacji.

Druga grupa dotyczy kwestii organizacyjnych wyjazdów - szczegółów trasy, typów aktywności podejmowanych w czasie podróży i form kontaktów z mieszkańcami. Autorka poszukuje odpowiedzi na pytanie o poczucie niezwykłości i niecodzienności doświadczenia turystycznego oraz uwzględnia zróżnicowanie doświadczeń i stylów podróżowania po Rosji.

Trzecia grupa zagadnień wiąże się z tożsamością podróżnika, ewentualnym poczuciem zmiany dokonującym się $\mathrm{w}$ trakcie wyjazdu bądź po powrocie 
do domu. Chodzi tutaj o pytanie, na ile kulturowa odmienność lub - przeciwnie - bliskość wpływa na zdobyte doświadczenie turystyczne.

Czwarta grupa pytań stawianych przez autorkę dotyczy wizerunku Rosji, który wyłania się z relacji podróżniczych. Zastanawia się, w jaki sposób wyjazd weryfikuje posiadaną wiedzę i zdanie na temat kraju, który pozostaje ważnym w kontekście doświadczenia granicy między Wschodem i Zachodem.

We wstępie książki, poza wspomnianymi celami, odnajdujemy szczegółowy opis analizy dyskursu, bazującego na zastanych materiałach wybranej literatury podróżniczej i analizie materiału uzyskanego podczas wywiadów (autorka przeprowadziła 28 wywiadów z 31 osobami w latach 2008-2011). Bachórz tłumaczy dobór interpretowanych tekstów oraz opisuje grupę biorącą udział w badaniu.

Początkowe rozdziały zawierają najważniejsze zagadnienia teoretyczne dotyczące podróży i turystyki. Choć, jak zauważa autorka, same praktyki turystyczne nie są głównym tematem studium, ich przybliżenie wydaje się niezbędne dla ukazania szerszego kontekstu międzykulturowego. I tak, autorka „wybiera” spośród refleksji na temat turystyki te zagadnienia, które dotyczą bezpośrednio osób podróżujących i ich doświadczeń. Na swój sposób ukazuje też różnicę między turystą a podróżnikiem, ostatecznie stojąc na stanowisku, że określeniami tymi będzie się posługiwać zamiennie. W dalszej części rozdziału znajdujemy informacje o typologii turystyki, doświadczeniu turystycznym oraz autentyczności i jej braku w doświadczeniu podróży.

Dalszą część pracy stanowią rozważania na temat orientalizmu i kulturowej granicy między światem zachodnim a światem określonym jako pozaeuropejski. Zagadnienie to zostaje w ciekawy sposób rozszerzone i włączone w kontekst postkolonialny, a następnie zastosowane do szerszej analizy zjawisk w Europie Środkowo-Wschodniej.

Autorka przybliża nam również analizę polskiego dyskursu podróżniczego na podstawie dostępnych publikacji i reportaży. Analizowane teksty w odniesieniu do przestrzeni i czasu zostały przedstawione w rozdziale trzecim, natomiast w czwartym odnajdujemy obraz Rosji jako miejsca biednego, utopijnego i zarazem nostalgicznego.

Ważną część książki stanowi analiza treści przeprowadzonych przez autorkę wywiadów. W Doświadczeniu turystyki i siebie w Rosji czytamy na temat zróżnicowania wyjazdów do tego kraju oraz indywidualnych doświadczeń i aktywności podejmowanych przez podróżujących. Ciekawym z geograficznego punktu widzenia wydaje się postrzeganie codzienności podróżników jako atrakcji turystycznej oraz doświadczanie siebie w kontakcie z Rosją poprzez łamanie dystansów (przezwyciężanie strachu przed krajem, dystans fizyczny, higiena, smak i zapach). W Doświadczeniach społecznych $w$ Rosji dowiadujemy się z kolei o znaczeniu kontaktów społecznych, często w kontekście podróży koleją transsyberyjską, stanowiącą nieustającą atrakcję turystyczną. Ze względu na kulturową bliskość i styl prowadzonych rozmów, język - z jednej strony - nie stanowi 
większego problemu, chociaż nieznajomość cyrylicy dla młodszego pokolenia bywa dużym utrudnieniem, np. w czytaniu map czy drogowskazów. W dalszej części pracy dowiadujemy się o relacji turysta - gospodarz, która z racji dylematów związanych z narodowościowym wymiarem i ambiwalentnymi odczuciami Polaków względem Rosjan bywa utrudniona. Doświadczenie kultury Rosji podejmuje tematykę obrony tego kraju przed polskimi narodowymi stereotypami, ze wskazaniem poczucia bliskości czy wręcz współdzielenia tej samej przestrzeni kulturowej (w relacji turysta - odwiedzany). Podróżujący marginalizują dziedzictwo kulturowe Rosji na rzecz piękna przyrody czy uczestnictwa w odwiedzanej codzienności. Zdecydowanie większym zainteresowaniem turystów cieszy się rosyjska prowincja, na przykładzie której widać zarówno poszukiwaną ,autentyczność", jak i oddalenie od cywilizacji oraz bogatego Zachodu.

W krótkim podsumowaniu autorka odnosi się do indywidualnych doświadczeń badanych turystów, podkreślając znaczenie jednostki dla całokształtu kulturotwórczego. Mówi też o poszukiwaniu nie tylko podobieństw, lecz także odmienności i różnorodności doświadczeń wielowątkowego, łączącego różne głosy dyskursu. Ukazanie dwóch obrazów Rosji - tej „dzikiej”, orientalnej oraz tej wyidealizowanej utopii - można odczytywać jako wykluczenie z przestrzeni zachodniej cywilizacji. Nie bez znaczenia jest miejsce Polski w analizowanym dyskursie. Odważne stwierdzenie Ziemowita Szczerka, że „jesteśmy zwykłym, ordynarnym Wschodem, tyle że w zachodnim opakowaniu", znajduje po części odzwierciedlenie w omawianej publikacji. Co więcej, autorka stara się wytłumaczyć i dociec - poprzez indywidualne głosy podróżujących - znaczenia nurtujących nas narodowych bolączek.

Na uwagę zasługuje bibliografia, licząca 286 pozycji w języku polskim i angielskim. W aneksie odnajdziemy spis i charakterystykę analizowanych w tekście źródeł książkowych, a także charakterystykę osób, z którymi autorka przeprowadziła wywiady. Załączony został scenariusz wywiadu i aneks zdjęciowy, obejmujący wybór fotografii z prywatnych archiwów rozmówców. Elementy te stanowią uzupełnienie bogatej treści książki.

Praca jest bardzo syntetyczna i gęsta, wymagająca skupienia. Publikacja zainteresuje nie tylko socjologów zajmujących się tematyką podróży, lecz także antropologów kultury, geografów i podróżników, którzy cenią sobie szczegółowe i wnikliwe analizy tematu.

W recenzji zamieszczonej na okładce książki czytamy o podjętej przez autorkę wielowątkowości tematu. Mowa jest też o wykraczającym poza socjologiczne ujęciu kontekstu międzycywilizacyjnego. Płynna poniekąd granica Wschodu i Zachodu została ukazana w subtelny sposób przez pryzmat doświadczeń grupy osób odwiedzających Rosję. Książka Agaty Bachórz to gruntowne studium, dające inne, nowe spojrzenie na problematykę podróży do Rosji i szeroko rozumianego Wschodu. Trzeba przyznać, że trudno nie zgodzić się z zaprezentowanym przez recenzentów stanowiskiem. 
Książka Rosja w tekście i doświadczeniu... nie jest jedyną, która porusza tematykę podróżowania Polaków do krajów Europy Wschodniej. Anna Horoltes w swojej pracy Konformizm, bunt, nostalgia. Turystyka niszowa z Polski do krajów bytego ZSRR (co ciekawe, podobnie jak publikacja Agaty Bachórz wydanej w 2013 r.) podejmuje próbę ukazania, w jaki sposób podróże kształtują tożsamość polskiego turysty ,alternatywnego”. Porównując obie prace, warto zwrócić uwagę na wykorzystanie przez autorki podobnego podejścia metodologicznego oraz kontekstu postkolonialnego dla ukazania specyfiki podróży do krajów Europy Wschodniej. Książka Agaty Bachórz w rzetelny sposób obrazuje naturę współczesnego podróżowania do Rosji - i nie tylko - choć na tym konkretnym przykładzie widać, że podjęta tematyka nie jest przypadkowa i z pewnością jest ważna we współczesnym dyskursie naukowym.

Podsumowując, należy podkreślić, iż omawiana publikacja niewątpliwie wnosi wkład w rozwój naukowy socjologii podróży, prezentując inne, świeże spojrzenie na problematykę wzajemnych relacji międzykulturowych. Polecam lekturę książki, po pierwsze, ze względu na jej zawartość merytoryczną, po drugie zaś - z uwagi na możliwość głębszej refleksji nad zjawiskiem podróżowania, które w dzisiejszych czasach bez wątpienia pozostaje zjawiskiem kulturowym.

\section{Bibliografia}

B a chórz A. (2013), Rosja w tekście i doświadczeniu. Analiza wspótczesnych polskich relacji z podróży, Zakład Wydawniczy NOMOS, Kraków.

Hor o let s A. (2013), Konformizm, bunt, nostalgia. Turystyka niszowa z Polski do krajów bytego ZSRR, Wydawnictwo Universitas, Kraków.

S z c ze re k Z. (2014), Nieznośnie wschodnia Polska, „Herito”, nr 15, s. 42-49. 